This PDF is a selection from an out-of-print volume from the National Bureau of Economic Research

Volume Title: Tax Policy and the Economy, Volume 12

Volume Author/Editor: James M. Poterba, editor

Volume Publisher: MIT Press

Volume URL: http://www.nber.org/books/pote98-1

Publication Date: January 1998

Chapter Title: Transition to and Tax-Rate Flexibility in a Cash-Flow-Type Tax

Chapter Author: David F. Bradford

Chapter URL: http://www.nber.org/chapters/c10916

Chapter pages in book: (p. 151 - 172) 


\section{TRANSITION TO AND TAX- RATE FLEXIBILITY IN A CASH-FLOW-TYPE TAX}

\section{David F. Bradford}

Princeton University

\section{EXECUTIVE SUMMARY}

The difficulty of making a transition from an income-type to a consumption-type tax is often cited as an obstacle to such a change in policy. Put simply, the problem is the double taxation of "old savings" or "old capital." A person who has accumulated wealth under an income tax will be hit with an extra tax on the consumption financed by that accumulation under a shift to a consumption tax. Such a transition effect raises issues of equity, political feasibility, and efficiency. In the typical implementation of a consumption tax, the same sorts of transition phenomena associated with a shift from an income tax follow from any change in the rate of tax. That is, introduction of a consumption tax is the same as raising the rate of consumption tax from zero to whatever positive rate is envisioned for the new system. Consequently, the problem of transition to a consumption tax generalizes to the problem of changing the rate of consumption tax.

In this paper I consider the design of rules that render consumption taxes in the family of business cash-flow taxes immune to the incentive

The author is Professor of Economics and Public Affairs, Princeton University; Adjunct Professor of Law, NYU Law School; Research Associate, National Bureau of Economic Research; and Adjunct Fellow, American Enterprise Institute. The research reported here has benefited from the financial support of the Woodrow Wilson School at Princeton and the John M. Olin Foundation and from the stimulating environment at the Center for Economic Studies of the University of Munich. Thanks also to Daniel Shaviro and Jane Gravelle, and to James Poterba, Michael Boskin, and other participants in the NBER teleconference on Asset Price and Transition Effects of Consumption Tax Reform, January 27, 1997. 
and incidence effects of changes in rate of tax. I show that two fairly simple approaches are available to deal with it: grandfathering the tax rate applicable to a given period's investment, or substituting depreciation allowances for the usual expensing of investment, coupled with a credit for the equivalent of interest on the undepreciated investment stock. A cost of this approach is its requirement to identify true depreciation and, in the second case, the real rate of interest.

In general, imposition of a consumption-type tax will cause a one-time loss to owners of certain assets. The loss will be spread over all wealth-owners to the extent the transition is accompanied by an unanticipated increase in the price level.

An anticipated introduction of a consumption tax, or an anticipated increase in its rate, for which no compensating transition rule is provided, will discourage saving and investing, encourage current consumption. (Bradford, 1996)

\section{INTRODUCTION}

This paper concerns a class of problems of implementation of and transition to consumption-type taxes. The specific issue that motivated this paper is transition to what I have called (Bradford, 1986) a two-tiered cash flow tax. The term refers to a two-component system. A single-rate business-level tax applies to the real cash flow of business firms (so investment is expensed), net of payments to workers. A personal-level graduated-rate tax applies to the workers' compensation. A good example is the flat tax, pioneered by Robert Hall and Alvin Rabushka (1983, 1995), which first brought this type of tax to my attention. In the flat-tax system, graduation in the compensation tax takes the particularly simple form of a tax-free allowance, based on family composition, together with application of the same rate paid by businesses to all amounts in excess of the exempt amount. ${ }^{1}$

Discussions of actual flat-tax proposals typically take for granted that a new system would replace the old as of some transition date. It seems much more likely, however, that if such a major change were to be undertaken a new system would be phased in over time. At the price of postponing the full achievement of whatever might be seen as the policy gains from the shift, the myriad transition incidence effects might

1 Other examples are my own loosely specified $X$ tax (Bradford, 1982) and Charles McLure and George Zodrow's simplified alternative tax, described in McLure, Mutti, Thuronyi, and Zodrow (1990) and in McLure and Zodrow (1991). 
thereby be adequately muted. ${ }^{2}$ Phase-ins of tax changes are notorious sources of complexity and opportunities for political machinations. I have argued in the past, however, that there is a way of phasing in a two-tiered cash-flow tax that would minimize these problems (Bradford, 1986, pp. 329-334). The simplicity of two-tiered cash-flow tax systems makes the apparently unthinkable quite reasonable, namely, running totally separate parallel tax systems for a period of years. ${ }^{3}$ The flat tax, for example, requires little, if any, information not required for the present-day income tax on individuals (including the tax on proprietors and partners) and corporations. It could easily be incorporated as an additional schedule on the existing individual and corporate tax returns. One possibility is to calculate tax under both systems. For an initial period, say two years, pay 80 percent of the bottom line of the presentday income tax and 20 percent of the bottom line of the new tax. During a second period, say the next two years, pay 60 percent of the bottom line of the present-day income tax and 40 percent of the bottom line of the new tax. At the end of this process, the tax is based 100 percent on the new system and the old system can be discarded. 4

Whatever the virtues of this adjustment process, it suffers from at least one clear disadvantage in the form of more or less (depending on the speed of the phase-in and the durability of the investment in question) severe disincentives for new investment. By the same token, disinvestment would be encouraged. New investment is immediately deducted in the calculation of business income under the new system. If the rate of tax were constant over time, by a familiar argument, the expensed deduction would just offset the taxation of subsequent returns for an investment that would barely break even in the absence of tax. The tax would thus be neutral with respect to the investment decision. But since the tax rate at which the deduction is made during the phase-in period is lower than the rate applied subsequently when

2 For a careful effort to model the trade-offs in alternative methods of introducing a reformed tax, see Zodrow (1981, 1985). Louis Kaplow (1986) and Daniel Shaviro (1997) develop the (sometimes unexpected) pros and cons of providing protection against statutory change.

${ }^{3}$ Lyon (1992) notes the ubiquity of parallel systems. A good, although perhaps not very happy, example is the alternative minimum tax for businesses and high-income individual taxpayers. Michael Graetz (1983) even argued that the minimum tax might serve the function of a bridge to a reformed income tax, along the lines of the process envisioned here.

4 The same transition plan could be effected by appropriate adjustments of all the rate and credit parameters of the old and new systems. The plan description has, however, the advantage of transparency. 
the investment's payoff comes in, a break even investment becomes a loser. ${ }^{5}$

It is readily seen that the investment-discouraging effect of a rising rate of tax during the phase-in to a cash flow business income base would characterize an increase in the rate for any other reason, as well. It is likely that policymakers will insist on having the option to change the rate of tax. They may, however, want to avoid the windfall gain and loss aspects of such changes. Taxpayers' anticipations of such changes will furthermore generate potentially large incentive effects. The problem that I describe in connection with a phase-in to such a tax therefore generalizes to a potentially serious problem of implementing a consumption tax on an ongoing basis. This paper is devoted to a discussion of methods of dealing with this problem.

In an appendix, I provide a formal model of the propositions developed verbally, but more generally, in the body of the paper. Throughout, I confine my attention to the partial equilibrium assumption that interest rates, and their generalization in a world with risk, are not affected by changes I consider. I believe that a more sophisticated modeling taking into account general equilibrium repercussions of changes in tax policy would not change the conclusions in any major way.

\section{TAX-RATE VARIATION IN A TWO-TIERED CASH- FLOW TAX}

As described, for example, in Bradford (1996), a useful way to think about a two-tiered cash-flow tax is to start with a subtraction-style valueadded tax. This is simply a tax at a single rate levied on all businesses, of whatever legal form. The base of the tax is the nonfinancial cash flow of the firm, that is, the difference between receipts from sales of goods and services of all kinds and purchases from other business firms. A twotiered cash-flow tax simply modifies such a subtraction-style valueadded tax by permitting firms to deduct as well their payments to workers (leaving the business tax). The payments to workers are, in turn, subject to the compensation tax.

The intertemporal rate variation problem is starkly manifested by the case of introduction of a subtraction-style value-added tax (the same would hold for a European-style invoice and credit value-added tax). I use a canonical example to convey the nature of the problem: a retail

5 An early discussion of the transition incentive problem is by Hall (1971). Hall has returned to the subject in (1996) and (1997). The problem is also discussed in Sinn (1987) and Howitt and Sinn (1989). 
store owner who buys a stock of canned tomato juice for $\$ 10,000$ the day before the tax goes into effect, with a rate, say, of 20 percent. If the tomato juice is sold the day after the introduction of the tax, for roughly $\$ 10,000$ (I assume a hotly competitive retail sector), the owner of the inventory will get to keep only $\$ 8,000$ after tax. This is because the cost of the goods sold is not allowed as a deduction. Rather, a deduction is allowed only for current purchases by the business.

The short-term inventory example, for which the element of waiting is negligible in the business calculation, gives a vivid instance of the impact of a rate change. The effect is the same for assets other than inventory, however. A person who bought a building the day before the introduction of the tax will suffer exactly the same loss, amounting to the new tax rate times the amount paid for the building, even though the cash payoff from holding the building may be years in the future. If that person were to sell the building for its current market value (presumably the same as the day before) the proceeds would be subject to the value-added tax. That is the justification for the commonly held view that imposition of a consumption tax imposes a one-time levy on "old wealth."

A typical statement of this position is my own, quoted at the head of this paper: "In general, imposition of a consumption-type tax will cause a one-time loss to owners of certain assets. ${ }^{16}$ I would note in passing that the words, "owners of certain assets," were carefully chosen. The loser in the tomato juice example is the owner of the inventory, who may not be wealthy at all; the inventory might have been financed by the issue of debt. That is why I went on to elaborate, "The loss will be spread over all wealth-owners to the extent the transition is accompanied by an unanticipated increase in the price level." An unanticipated general price level change, which is not a necessary concomitant of the introduction of a value-added tax, would have the usual effect of penalizing net nominal creditors. A price level change (unanticipated) in exactly the amount of the tax, often taken for granted by commentators, would effectively spread the transition tax over wealthholders in general. (So the illustrative holder of debt-financed inventory would not suffer any transition tax burden.)

Although my words were carefully chosen, they were, perhaps, not sufficiently so. As has been pointed out to me by Daniel Shaviro, I could equally well have written, "In general, imposition of an income-type tax using a present-value depreciation scheme will cause a one-time loss to own-

${ }^{6}$ Other examples include Gravelle (1995); Altig, Auerbach, Kotlikoff, Smetters, and Walliser (1997) show, in simulations of transitions to VAT, flat, and X taxes, how important the issue may be. 
ers of certain assets." An example of a present-value depreciation scheme is the proposal by Auerbach and Jorgenson (1980) to substitute an up-front deduction at the time of acquisition of an asset equal to the discounted value of future depreciation allowances, in place of the normal year-by-year depreciation deductions. Upon introduction of such a system (or upon transition to it from the usual income accounting) there would be a one-time loss to owners of business assets, exactly like the tax on the inventory-holder in the example of a subtraction-style valueadded tax. Similarly, changes in the rate of tax in a system with Auerbach-Jorgenson present-value depreciation would result in losses (for a rate increase) or gains (for a rate cut) to owners of existing assets. The transition effects are not due to the economic character of the tax but to the method of its implementation.

\subsection{Insulating against Tax-Rate Changes: Grandfathering}

It seems evident in the case of a switch in methods of accounting for depreciation in an income tax that the way to eliminate the transitionincidence effect would be to do something like "grandfather" the depreciation allow ances of assets acquired before the new system was introduced. The same holds for the consumption-type tax. In the example of the tomato juice inventory, grandfathering means looking back to the purchase of the asset in the pre-transition period and allowing a current deduction in the new system. Generalized to the broader system of income accounting, grandfathering calls for allowing the owner a deduction for the current market value of business assets. In a well-constructed system of income accounting (including adjustment for inflation) this would be called in income-tax jargon the "basis" (acquisition value less cumulative depreciation allowances, for example) of business assets.

As I have emphasized, changes in the rate of a subtraction-type valueadded tax (or the business tax rate in a two-tiered cash-flow tax) generate the same incidence and incentive effects as the transition from the no-tax situation. Eliminating these transition effects can be accomplished by the same grandfathering method as just described. Upon a change in the rate, the owner would be allowed a credit in the amount of the product of the basis of business assets and the increase in the rate of tax. So, for example, an increase in the rate of tax from 20 to 25 percent would give rise to a credit of 5 percent of basis. ${ }^{7}$

To serve the function of eliminating transition incentives due to taxrate changes, "economic" depreciation-the change in an asset's market

${ }^{7}$ English and Poddar (1995) have developed a scheme along these lines to deal with rate changes in a value-added tax that includes financial institutions. 
value during the period-is required. That is, there will be transition incentives unless the basis of assets equals their market values. To implement the required grandfathering policy perfectly would require true, inflation-corrected depreciation adjustments. Indeed, the accounting really required is mark-to-market valuation. Suppose, for example, the illustrative tomato juice inventory is purchased on day -2 . On day -1 , a disastrous frost wipes out the tomato-juice crop, so the canned stock jumps in market value from $\$ 10,000$ to $\$ 20,000$. On day 0 , the new tax goes into effect, and on day +1 , inventory is sold for $\$ 20,000$. To make the juice-holder whole requires a credit of 20 percent of $\$ 20,000$, not 20 percent of $\$ 10,000$ as historical-cost accounting would suggest. ${ }^{8}$

\subsection{Insulating against Tax-Rate Changes: Depreciation plus Interest on Basis}

The requirement of good economic income accounting is clearly an obstacle to practical implementation of insulating the system from rate-change effects, on which I have a bit more to say below. Another obstacle seen by many commentators who have considered a switch from an income- to a consumption-based tax system is the huge one-time revenue cost due to the write-off of the entire depreciation basis at the time of transition. Viewed in terms of the long-term budget constraint, this revenue cost is simply the requirement of avoiding the one-time extra tax on those affected by the transition over what might, arguably, be considered the intent of introducing the new tax. ${ }^{9}$ Because, however, the revenue cost occurs in a lump at the time of introducing the consumption-based tax, it is generally seen as posing a large fiscal challenge.

The solution to this problem is simple enough: The tax allowance could be given in the form of government IOUs. That is, instead of allowing an immediate write-off of basis at the time of transition, the transition rule could provide a path of tax rebates or other transfers over time with the same discounted value. ${ }^{10}$ This would be the equivalent of

${ }^{8}$ An instance of a somewhat similar transition phenomenon was the impact of lower rates of tax, enacted in the Tax Reform Act of 1986, on the return flow from assets for which accelerated depreciation had been taken in earlier years. In that case, a windfall gain was involved. Zodrow (1988) presents an analysis of the effort to neutralize this change.

9 The idea that consumption out of past accumulation "ought" not to be taxed is perhaps most plausible in connection with a shift from an income tax, under which the past accumulation has been taxed already. To be sure, some argue that an extra tax based on past accumulation is a desirable policy objective (see, for example, Kotlikoff, 1992).

10 Boadway and Bruce (1984) exploit this equivalence in their suggested design of a neutral business tax. 
allowing the write-off and issuing debt, but would show up differently in the fiscal bookkeeping. ${ }^{11}$

A particular form of this alternative policy turns out to have a very convenient property of eliminating the need for specific adjustments to take account of changes in the rate of tax. Under the alternative policy, the taxpayer is allowed a deduction for the decline over time in the value of business assets ${ }^{12}$ plus a deduction for the cost of carrying the capital reflected in the value of those assets. Practically speaking, this implies using income accounting for business income with the addition of a capital cost allowance equal to the going rate of interest times the tax basis in the business (including basis in inventory). (Since the objective is a real-income measure, the depreciation and similar allowances would be adjusted for inflation. Similarly, the interest rate applied to basis would be a real, inflation-adjusted measure. ${ }^{13}$ )

If the rate of tax is constant over the life of the investment, the suggested policy is evidently equivalent to the expensing characteristically associated with consumption taxation. The difference is that the tax benefit ordinarily obtained due to expensing is received over time, with interest. "Basis" is simply the part of the value of assets that has not yet been taken as a deduction that "should" have been allowed, so the taxpayer is compensated with an interest allowance.

With a constant rate of tax, all schemes that provide an interest compensation for delayed receipt of benefits will be equivalent from the point of view of the taxpayer. It may be less clear, but is true, that the specific form, deduction of economic depreciation plus the interest rate times the basis in business assets, is unique in incorporating just the right adjustment to achieve neutrality in the face of intertemporal variation in the rate of tax. This point is perhaps best established by considering the alternative and most easily understood in the contest of introduction of a new tax. Suppose the basis, reflecting the amount that has not yet been allowed as a deduction (from the zero-rate tax), is different from the market value of the asset. That is, suppose something other than economic depreciation has been used in determining the

11 Kotlikoff (1992) has emphasized the arbitrary nature of fiscal accounting as a system of "labels" on cash flows.

12 I apply the term "economic depreciation" to this amount, even though the adjustment may involve something more than is suggested by this accounting terminology. In particular, the decline could be negative.

13 Essentially this method has been implemented in Croatia, as described by Rose and Wiswesser (1997), who played a role in designing the new system. An important intellectual predecessor was Wenger (1983). 
amount subject to the new depreciation cum carrying-cost deduction. To be specific, suppose depreciation is accelerated, relative to economic depreciation, so that the basis is below market value. Now a tax is imposed at a positive rate, which will stay constant in the future. The taxpayer will obtain the equivalent, in present-value terms, of the deduction of basis at the transition date. But we know that deduction of the market value of the asset is required to eliminate a loss in asset value at the transition date, and therefore to eliminate the incentive to disinvest prior to the transition date.

By a similar argument, if depreciation allowances for the pre-transition period are below economic depreciation, the basis in the asset will exceed the market value at the transition point. Then the allowance at the transition date, economically equivalent to write-off of basis at the new tax rate, will be too high, in the sense that the taxpayer will experience a jump in asset value and an extra incentive to invest prior to an anticipated transition. Economic depreciation, coupled with deduction of interest on basis, is "just right" in a world of changing tax rates.

\section{COMMENTARY}

\subsection{Measuring Depreciation}

A very big drawback of both approaches is their requirement for wellmeasured, inflation-corrected depreciation allowances. Currently, in the United States there is no correcting for inflation in either tax or financial accounts, in spite of arguably significant mismeasurement as a result. One of the most serious obstacles to inflation adjustment is the appropriate treatment of interest. Fortunately for the feasibility of the schemes described in this paper, interest payments and receipts are not included in the tax base. Adjustment of the purely real side of the accounts is likely to be more manageable. ${ }^{14}$

Even inflation-corrected historical-cost accounts may still produce rather poor approximations to current market values. In Bradford (1991) I presented data on the ratio of the aggregate market value of equity in U.S. corporations to the net worth of the U.S. nonfinancial corporate business sector to the consolidated financial accounting measure of net worth (incorporating Commerce Department data on the corresponding inflation-adjusted capital stocks). Over the period 1948 to 1987 the ratio varied widely, with a high (in 1968) of 110 percent and a low (in 1974) of 37 percent. Although one can reasonably quibble with the details of this

14 For a discussion of the issues, see Shoven and Bulow (1975). 
calculation, it does suggest that historical-cost accounting is unlikely to be a particularly accurate measure of current value.

One important source of divergence between any measure of the tangible assets of a business and the market value of that business are the intangible assets with which they are combined. In the "information age $^{\prime \prime}$ it seems likely that intangible assets, such as trade marks, marketing skills, software copyrights, and so on, account for an increasing fraction of wealth. Consider, for example, an investment in a marketing campaign to promote the popularity of a brand of running shoes. Under present tax (and financial) accounting procedures, the outlays on the campaign would be deducted currently, even though they are likely to produce sufficient extra future profits to justify the expense. In tax jargon, the basis in such an intangible asset is zero. Presumably, however, the anticipation that a tax would be introduced between the time of making the outlay and the realization of the payback would have the effect of discouraging the investment. Short of marking the value of the firm to market, there does not seem to be any practical way to avoid such mismeasurements.

As in the income tax, there is a remedy available to the taxpayer with basis different from market value: realize any gain or loss by selling the asset. (I neglect here niceties of the limits placed by actual income-tax rules on such transactions.) In a world without transaction costs, this option (since it is an option) can only work to the taxpayer's advantage. Such realization transactions have been sufficiently attractive in the past in the case of residential real estate (where a differential between capital gain and ordinary income tax rates was involved) to generate significant activity. It can probably be taken for granted, however, that the tax stakes are unlikely to motivate significant asset trading in the case of the transition situations envisioned in this analysis.

The key requirement is to measure correctly the cumulative total in real terms (hence the importance of inflation correction). If the cumulative total of allowances adds up to the cost of the asset, the problems are due to timing effects, which are important in an income tax but not in a constant-rate cash-flow tax. In the context of a cash-flow company tax, timing matters only when there is intertemporal rate variation. For taxrate changes of the sort one is likely to anticipate (compare, say, the rate changes enacted in typical value-added tax systems), the distorting effects of mismeasurement should be minor. As is touched upon below, in the case of the transition effects upon introduction of a two-tiered cashflow tax, there would, in addition, be offsetting incentives from the residual income tax (which is on a realization basis). 


\subsection{Special Aspects of the Transition from an Income Tax}

The phase-in transition to a cash-flow tax discussed in this paper would be accompanied by a corresponding phase-out transition from the income tax. If the existing tax system were well modeled by an accrual income tax, the latter process should be free of the transition incidence and incentive effects examined here. This is because neutrality with respect to intertemporal variation in the tax rate is a (not very wellknown) property of an ideal income tax. "Ideal" here means a mark-tomarket accrual tax, which perforce implies economic depreciation..$^{15}$

The actual income tax differs, however, from the accrual ideal. Separate taxes at the individual and corporate level and the intricate rules relating to the financial structure of corporations greatly complicate the problem of sorting out transition effects. This is why the gradual process of transition might be attractive. The central phenomenon considered in this paper is the incentive to alter investment owing to the interaction with a changing rate of tax and the recovery of basis in business investments. The main "defect" of the income-measurement system in this regard is accelerated depreciation of depreciable assets and complete write-off of investment in "self-constructed" intangible property. Ordinarily, a declining rate of income tax works to increase the attractiveness of such investments (and, in effect, to forgive taxes that would have been expected on the return flow from past breakeven propositions). It is a convenient property of the simultaneous phasing out of one tax and phasing in of the other that this class of distortions under the imperfect income tax would be roughly neutralized.

\subsection{Concluding Comments}

Three factors favor the depreciation-with-interest method over the grandfathering method of dealing with transition (and with the ongoing problem of rate changes). First, the former method would be effective in neutralizing investment incentive effects in a situation in which the marginal rate of tax varies over time for an individual taxpayer. Grandfathering requires keeping track of the time path of marginal rates, a possible

15 The proposition that, provided a deduction for economic depreciation is allowed, the choice among assets according to durability is undistorted by a flat-rate income tax is called by Sinn (1987) the Johansson-Samuelson theorem, referring to Johansson (1969) and Samuelson (1964). Although Johansson (1969, p. 110) seems to have anticipated the fact that these neutrality results carry over to the case of time-varying tax rates, Samuelson (1964) did not. It was spelled out by Sandmo (1979) and Lyon (1990). 
complication. To be sure, the theoretical two-tiered cash-flow tax has a single business tax rate applicable to all taxpayers at any time. In a realworld application, however, there might well be limits on loss offsets and similar features that would render the tax schedule nonlinear.

Second, grandfathering carries with it a large revenue cash-flow shortfall at the time of introduction of a two-tiered cash-flow tax, with similar lumpy effects at the time of any rate change. As discussed above, these effects could be offset by granting a rebate in the form of a smoothed stream of payments with the same present value. This would, however, add a nontrivial complication to the operation of the system.

Third, because depreciation-with-interest-on-basis results in neutrality toward business investment under a constant tax rate, regardless of whether the depreciation allowances match the economic levels, this method takes some of the pressure off of this difficult administrative problem. ${ }^{16}$ Getting the timing of allowances wrong affects only the transition incentives. If the rate changes are small in the cash-flow tax (typical rate changes in European value-added taxes might serve as a basis for comparison), transition incentives would also be small unless the timing deviation were very large. Adjusting allowances for inflation would remain critical, but since the appropriate adjustments are conceptually fairly simple and would be the same for all assets, this may be less of a problem.

The main disadvantage of the depreciation-with-interest method is its requirement to identify the appropriate real discount rate. Conceptually, this choice is clear enough in the world without transaction costs that underlie the investment model used in deriving the scheme. In that world, the investor always has the option of financing with riskfree debt. Everyone is indifferent between $\$ 1$ now and $\$(1+i)$ a year from now, where $i$ is the risk-free interest rate. Since the government guarantees the interest on postponed depreciation deductions, the appropriate interest rate to use is the short-term government borrowing rate (inflation-indexed).

To determine how this conclusion would be modified in the light of more realistic assumptions about the financial environment would merit exploration. Transaction costs could imply that an investment that would be attractive in the absence of taxes, or with immediate expensing in a cash-flow tax framework, could not be financed under the depreciationwith-interest method. On the other hand, the value of the future tax deductions would seem to be comparable as collateral to the asset itself. More difficult to sort out is the influence of uncertainty about the reliabil-

${ }^{16}$ This is the point of Boadway and Bruce (1984). 
ity of the government's commitment not to change the policy. ${ }^{17}$ (Since the policy could become more favorable, rather than less, the influence of this form of risk on the investment decision is, perhaps, ambiguous.)

It is appropriate to conclude with this hint of the political process. This paper concerns the possibility of carrying out a smooth transition from the existing, messy income tax to a two-tiered cash-flow tax. The main reasons one might want to undertake this transition are the superior simplicity and neutrality properties of the new system. The warning may bear repeating, therefore, that these attractive properties, which result from the ability to exclude financial instruments from the tax calculation and-from the relatively simple business accounting, would not necessarily be proof against a complex political process. ${ }^{18}$ Adding, as the suggested transition scheme would, a requirement for inflationcorrected depreciation and an allowance of interest on undepreciated basis solves some problems but introduces others of a political nature, since someone has to specify the depreciation rules and interest rate.

\section{APPENDIX: FORMAL MODELING}

In the body of this paper I have used verbal, although I believe general and rigorous, arguments. In this appendix I present a mathematical formulation of the results, using the exponential-decay model of capital familiar to economists since at least the famous Hall and Jorgenson paper (1967). A typical productive asset ("machines") is assumed, in effect, to shrink over time to successively smaller replications of itself. A unit machine of durability $\delta$ is transformed by the passage of time into $e^{-\delta_{s}}$ units of the same machine, where $s$ is the time since putting the machine in service. The set of available technologies is assumed to be represented by machines of durabilities $0 \leqslant \delta \leqslant \infty$. The value of the output, net of other input costs, of machines of each durability is subject to diminishing returns relative to the cost of the machine (which might be the consequence of a diminishing price at which the particular good produced can be sold) and is determined in equilibrium.

The exponential-decay, or proportional-depreciation, model is commonly used for such analyses primarily because it can be manipulated easily. It should be kept in mind, however, that there is no particular reason to believe that it fits the facts of investment opportunities. As

17 For a study that demonstrates both the reality of risk of changes in policy and the potential effect on investment incentives, see Auerbach and Hines (1987).

18 For an extended discussion of the political forces at work in alternative tax regimes see Paul (1997) and my commentary (Bradford, 1997). 
discussed in the body of the paper, however, the conclusions reached here with regard to the exponential-decay model carry over to a consistent mark-to-market income measurement system. ${ }^{19}$

As is also typical, I assume a one-good world, in the sense that a unit machine is assumed costlessly convertible into a unit of the single good. It follows that the value of one unit of any machine depreciates at a rate $\delta e^{-\delta s}$ at age $s$.

\section{A.1 Rate Changes Unimportant under an Income Tax}

A.1.1 The Analysis without Taxes Suppose a unit of asset of type $\delta$ throws off an annual gross rental (gross of any depreciation in the machine but net of payments to any collaborating factors) of $c(\delta)$. Then, in the absence of taxes and risk, and with the option to borrow and lend at interest rate $i$, a capitalist will value a unit asset of type $\delta$ at

$$
\int_{0}^{\infty} c(\delta) e^{-(\delta+i) s} d s=\frac{c(\delta)}{i+\delta}
$$

Note that this is an arbitrage argument. The arbitrage is with the alternative opportunity by which the interest rate is defined, which I have here represented as interest-bearing debt. If the asset could be purchased for less than this demand price, by borrowing at the going interest rate, a capitalist could purchase a machine and arrange for a net cash flow that is positive over some time interval and never negative. Likewise, if the going price of the asset is less than the demand price, the owner of a machine could produce a strictly positive net cash flow over some interval by a combination of selling the machine and lending the proceeds.

Since a unit machine costs 1 , then for demand and supply for machines to be equated it must be true for each durability used,

$$
\frac{c(\delta)}{i+\delta}=1, \quad i=c(\delta)-\delta
$$

The before-tax or social rate of return, $r(\delta)$, is defined implicitly by the internal rate of return on investment in a machine of the given durability:

$$
\int_{0}^{\infty} c(\delta) e^{-[\delta+r(\delta)] s} d s \equiv 1
$$

19 For proper income measurement, both the interest rate and any depreciation or similar adjustments should be on an inflation-corrected basis. 
That is,

$$
r(\delta)=c(\delta)-\delta
$$

So with no taxes, the social rate of return on all machines of all durabilities in positive use will be equal in asset market equilibrium, and equal to the interest rate,

$$
r(\delta)=i
$$

If the (instantaneous) interest rate is a known function of time, $i(t)$, instead of a constant, these expressions and ideas need to be generalized. Then, the equilibrium net rental thrown off by a unit machine will also typically be a function of time, which I write as $c(t)$ (changing the argument from $\delta$ ), and the demand price for an asset of durability $\delta$ is

$$
\int_{0}^{\infty} c(s) e^{-\delta s-\int_{0}^{s}(\xi) d \xi} d s .
$$

In general, the demand price of an asset now depends on the anticipated time path of future net rentals and interest rates. If, however, it is anticipated that the net rental rates and interest rates will be related by

$$
i(t)=c(t)-\delta,
$$

then the demand price will equal

$$
\int_{0}^{\infty}[i(s)+\delta] e^{-\delta s-\int_{0}^{s} i(\xi) d \xi} d s .
$$

This integral is of the general form

$$
\int_{0}^{\infty} f^{\prime}(s) e^{-f(s)} d s=-\left.e^{-f(s)}\right|_{0} ^{\infty}
$$

In the present case $-e^{-f(\infty)}=0$ and $-e^{-f(0)}=1$; the demand price equals the supply price, validating the fact that $c(t)=i(t)+\delta$ will equate demand and supply for machines. In this context we need also to substitute the instantaneous social or before-tax yield,

$$
r(t)=c(t ; \delta)-\delta
$$

for the yield-to-maturity formulation that is appropriate for the constantstationary-state story (where I have added the durability argument to the expression for gross rental to emphasize that at any given time there will be many margins of return to investment). 
A.1.2 Adding Income Taxes As background for the analysis of consumption taxes, it is useful to review the equilibrium conditions when an income tax at rate $m$ applies to gross rent, with an allowance for actual ("economic") depreciation and a deduction for interest (which is, in turn, taxed to the recipient). By the same arbitrage argument as used before (trading off the after-tax consequences of buying a machine with the after-tax consequences of lending at taxable interest), in the stationary state, with constant interest and gross rental rates, the demand price for a unit asset of durability $\delta$ will be

$$
\int_{0}^{\infty}[(1-m) c+m \delta] e^{-[\delta+(1-m) i] s} d s=\frac{(1-m) c+m \delta}{(1-m) i+\delta}
$$

Equilibrium in asset markets requires that this demand price be equated to the supply price (which is 1 ),

$$
\frac{(1-m) c+m \delta}{(1-m) i+\delta}=1
$$

which implies further

$$
i=c-\delta \equiv r(\delta)
$$

for all $\delta$. [Reminder: In equilibrium, $c=c(\delta)$.] The implication that, provided a deduction for economic depreciation is allowed, the choice among assets according to durability is undistorted by an income tax is called by Sinn (1987) the Johansson-Samuelson theorem.

It is important to be clear about what it is that is not distorted. In the equilibrium with the income tax, the social rate of return, $r$, is equated on all assets. This follows immediately from the observation that equilibrium requires that $r(\delta)=i$ for machines of all durabilities employed in positive amount. Given the interest rate $i$, the tax rate $m$ has no influence on the level of investment in machines of any durability. (As has been mentioned, this result is general, and not dependent on the exponential depreciation structure, although defining economic depreciation is not so easy once one leaves the simple model. In particular, if investment is irreversible, the time path of interest rates may matter. Risk is also likely to play a more important role in the analysis. So long, however, as true market value is used as the basis for the depreciation allowances, the propositions discussed in this appendix will hold.) There is, however, a distortion in the model due to the deviation between the after-tax yield 
on savings, $(1-m) i$, and the common before-tax yield on investment, $r$. A change in the income tax rate will, in general, influence investment levels via its general equilibrium impact on the desired stocks of wealth and, hence, the interest rate. More important, there will, in equilibrium, be a difference between savers' marginal rate of time preference and the social rate of return on investment.

A convenient property of an income tax is that these neutrality results carry over to the case of time-varying tax rates. Given the path of interest rates, anticipated changes in the rate of a true income tax (with economic depreciation) have no effect on the current level of investment. (In general equilibrium one would expect tax-rate changes to produce changes in the path of the interest rate, which would have an impact on asset prices if investment is not reversible.)

To see how this conclusion emerges from the formal model, we examine the breakeven requirement for the case of a time-varying tax rate (for simplicity, keeping the assumption of a constant interest rate). The demand price for a unit asset of durability $\delta$ will then be

$$
\int_{0}^{\infty}\{[1-m(s)] c(s)+m(s) \delta\} e^{-\delta s-\int_{0}^{s}[1-m(\xi)] i d \xi} d s .
$$

As in the no-tax case with varying interest rate, the current demand price depends upon current and future gross rental and net tax rates. We can check that the condition $i=c(s)-\delta$ will be an equilibrium relationship; in this case, the breakeven condition would imply

$$
\begin{gathered}
\int_{0}^{\infty}\{[1-m(s)](i+\delta)+m(s) \delta\} e^{-\delta s-\int_{0}^{s}[1-m(\xi)] i d \xi} d s \\
=\int_{0}^{\infty}\{[1-m(s)](i)+\delta\} e^{-\delta s 1 \int_{0}^{s}[1-m(\xi)] i d \xi} d s .
\end{gathered}
$$

As before, the integral is of the general form

$$
\int_{0}^{\infty} f^{\prime}(s) e^{-f(s)} d s=-\left.e^{-f(s)}\right|_{0} ^{\infty}
$$

and, as before, $-e^{-f(\infty)}=0$ and $-e^{-f(0)}=1$; the demand price equals the supply price, validating the fact that $c(t)=i(t)+\delta$ will equate demand and supply for machines.

\section{A.2 Rate Changes May Matter under a Business Level Cash-Flow Tax}

With a proportional cash-flow tax on business investment at rate $m$, constant through time, the net cash flow of a capitalist who purchases a machine is simply a proportion $1-m$ of what it would be in the absence 
of the tax. The net-of-tax gross rental from a unit machine ("gross" here refers to the treatment of depreciation) is reduced by the fraction $m$, but so is the cost to the capitalist of buying the asset. By the same arbitrage (with debt) argument as we used in the no-tax environment, the capitalist's demand price for an asset is given by

$$
\int_{0}^{\infty}(1-m) \mathcal{c}(\delta) e^{-(\delta+i) s} d s=\frac{(1-m) \mathcal{c}(\delta)}{i+\delta}
$$

but because the net-of-tax cost to the capitalist of acquiring a machine is $1-m$ instead of 1 , equilibrium still implies

$$
i=\mathcal{c}(\delta)-\delta
$$

So, given the interest rate, the tax rate has no effect on investment. [Sinn (1987) calls this result the Brown theorem, referring to E. Cary Brown (1948).] Here the neutrality carries over to the saving decision as well as the durability of machines in equilibrium. That is, in equilibrium, the intertemporal marginal rate of substitution of consumers equals the social rate of return.

Intertemporal variation in the interest rate affects this argument in exactly the same way as it affected the story in the case without taxes. Intertemporal variation in the tax rate is, however, another matter. The tax rate determines the fraction of a newly purchased machine that is financed by tax savings due to the expensing of the purchase. If that fraction is not matched by the fraction of the future cash flow that is taken away by the tax collector, an investment that breaks even in the absence of taxes will no longer break even with taxes. If the future tax rate is higher than the present rate, a breakeven investment becomes a loser and it becomes a winner if the future tax rate is lower than the present rate.

To take a simple example, suppose the business tax rate is rising over time in such a way that the fraction of the payoff of an investment retained by the owner declines at some multiple of the rate of interest:

$$
1-m(s)=[1-m(0)] e^{-a i s} .
$$

Then the breakeven condition for an investment would be

$$
\int_{0}^{\infty}[1-m(s)] c(\delta) e^{-(\delta+i) s} d s=\int_{0}^{\infty}[1-m(0)] c(\delta) e^{-[\delta+(1+\alpha) i] s} d s=1-m(0),
$$


which reduces to

$$
(1+a) i=c(\delta)-\delta
$$

The effect of the rising business tax rate is equivalent to an increase in the interest rate. Its impact is identical to that of a uniform income tax.

Introduction of a cash-flow tax, from no tax, corresponds to intertemporal variation in the business tax rate from zero to some positive amount. If the introduction is unanticipated, owners of machines in effect give up a fraction $m$ of their assets. If the tax-rate change is anticipated, there are incentive effects on investment.

\section{A.3 Neutralizing Transition Effects in a Business Cash-Flow Tax Regime}

We can use the exponential decay case to model the two methods of neutralizing the transition effects described in the body of the paper:

1. Investment expensed and tax treatment "grandfathered."

2. Only economic depreciation allowed, instead of expensing, but with an additional deduction equal to the rate of interest times the undepreciated basis of business assets.

In both cases, there is assumed to be no taxation of interest received or deduction of interest paid.

A.3.1 Method (1): Grandfather Tax Treatment The idea is to compensate the investor for an increase in the tax rate, or to extract a payment for a cut in the tax rate. In a discrete model, to grandfather the tax treatment of past investment if the tax rate goes up from $m(t-h)$ to $m(t)$, the owner of the asset is provided a tax rebate of $m(t)-m(t-h)$ times the "unused basis" in the asset. The latter will (in equilibrium) be the amount of the asset remaining after deducting economic depreciation since acquisition. [This is speaking loosely. In this case, the basis is actually zero, since the asset is expensed in method (1).]

In the instantaneous version of this method, with tax rate as a function of time, $m(t)$, there is a rate of rebate equal to $m^{\prime}(t)$ times the undepreciated basis. If the rental rate $c$ is constant, the basic economics of the investment is described by

rent after tax: $\quad\left\{[1-m(s)] c+m^{\prime}(s)\right\} e^{-\delta s}$;

machine costs: $1-m(0)$. 
Eliminating the opportunity for arbitrage profit requires

$$
\int_{0}^{\infty}\left\{[1-m(s)] c e^{-\delta s}+m^{\prime}(s) e^{-\delta s}\right\} e^{-i s} d s=1-m(0) .
$$

We know that with a constant tax rate the breakeven rental rate is given by

$$
c=i+\delta \text {. }
$$

We need to check that this will still present a breakeven investment opportunity when the tax rate is varying over time.

Integrating the left-hand side by parts,

$$
\begin{aligned}
& {\left.[1-m(s)] e^{-(i+\delta) s}\right|_{0} ^{\infty}-\int_{0}^{\infty}\{[1-m(s)] c-(i+\delta)[1-m(s)]\} e^{-(i+\delta) s} d s} \\
& \quad=\left.[1-m(s)] e^{-(\delta+i) s}\right|_{0} ^{\infty}-\int_{0}^{\infty}\{[1-m(s)][c-\delta-i]\} e^{-(\delta+i) s} d s \\
& \quad=1-m(0),
\end{aligned}
$$

\section{Q.E.D.}

A.3.2 Method (2): Economic Depreciation plus Interest on Basis In method (2) the investor pays income tax, using economic depreciation rather than expensing of new investment, but there is allowed in addition a deduction for the cost of carrying the capital, in the form of the rate of interest times the remaining basis. If the rental cost $c$ is constant, the cash flows are described by

$$
\begin{array}{ll}
\text { rent after tax: } & \{[1-m(s)] c+m(s)(i+\delta)\} e^{-\delta s} ; \\
\text { machine costs: } & 1 .
\end{array}
$$

Eliminating the opportunity for arbitrage profit requires

$$
\begin{array}{r}
\int_{0}^{\infty}\{[1-m(s)] c+m(s)(i+\delta)\} e^{-(i+\delta) s} d s=1 \\
\int_{0}^{\infty}[c-m(s)(c-i-\delta)] e^{-(i+\delta) s} d s=1 .
\end{array}
$$

As before, use the fact that with a constant tax rate the breakeven rental rate is given by

$$
c=i+\delta
$$

If this continues to hold, we can substitute into the equilibrium condition, which becomes

$$
\int_{0}^{\infty} c e^{-(i+\delta) s} d s=1
$$

which we know to hold. 


\section{REFERENCES}

Altig, David, Alan Auerbach, Laurence Kotlikoff, Kent Smetters, and Jan Walliser, (1997). "Simulating U.S. Tax Reform." Washington, DC: U.S. Congress, Congressional Budget Office. September.

Auerbach, Alan J., and James Hines (1987). "Anticipated Tax Changes and the Timing of Investment." In The Effects of Taxation on Capital Accumulation, Martin Feldstein, (ed.). Chicago: University of Chicago Press.

_- , and Dale Jorgenson (1980). "Inflation-Proof Depreciation of Assets." Harvard Business Review, September/October.

Boadway, Robin, and Neil Bruce (1984). "A General Proposition on the Design of a Neutral Business Tax." Journal of Public Economics, XXIV:231-239.

Bradford, David F. (1982). "The Choice between Income and Consumption Taxes." Tax Notes, XVI(8, August 23):715-723. Revised version in New Directions in Federal Tax Policy for the 1980s, Charls E. Walker and Mark A. Bloomfield (eds.). Cambridge, MA: Ballinger.

(1986). Untangling the Income Tax, Cambridge, MA: Harvard University Press.

(1991). "Market Value versus Financial Accounting Measures of National Saving." In National Saving and Economic Performance, B. Douglas Bernheim and John B. Shoven (eds.). Chicago: University of Chicago Press.

(1996). "Consumption Taxes: Some Fundamental Transition Issues." In Frontiers of Tax Reform, Michael J. Boskin (ed.). Stanford, CA: Hoover Institution Press.

(1997). "What's in a Name? Income, Consumption, and the Sources of Tax Complexity." Forthcoming in University of North Carolina Law Review.

Brown, E. Cary (1948). "Business Income Taxation and Investment Incentives." In Income, Employment and Public Policy: Essays in Honor of A. H. Hanson, L. A. Metzler, E. D. Domar, et al. (eds.). New York: W. W. Norton.

English, Morley D., and Satya Poddar (1995). "Taxation of Financial Services under a VAT: Applying the Cash-Flow Approach." October. Manuscript.

Graetz, Michael J. (1983). "The 1982 Minimum Tax Amendments as a First Step in the Transition to a 'Flat Rate' Tax." Southern California Law Review LVI (January):527-571.

Gravelle, Jane G. (1995). "The Flat Tax and Other Proposals: Who Will Bear the Tax Burden?" Washington, DC: U.S. Congress, Congressional Research Service. November 29. Report 95-1141 E.

Hall, Robert E. (1971). "The Dynamic Effects of Fiscal Policy in an Economy with Foresight." Review of Economic Studies XXXVIII(April 1971):229-244.

- (1996). "The Effects of Tax Reform on Prices and Asset Values." In Tax Policy and the Economy (X), James Poterba (ed.). National Bureau of Economic Research, MIT Press.

- (1997). "Potential Disruption from the Move to a Consumption Tax." American Economic Review, Papers and Proceedings, LXXXVII (May):147-150.

, and Dale W. Jorgenson (1967). "Tax Policy and Investment Behavior." American Economic Review LVII(3, June):391-414.

, and Alvin Rabushka, (1983). Low Tax, Simple Tax, Flat Tax. New York: McGraw-Hill.

- and - (1995). The Flat Tax, 2nd ed. Stanford, CA: Hoover Institution Press. 
Howitt, Peter, and Hans-Werner Sinn (1989). Gradual Reforms of Capital Income Taxation. American Economic Review LXXIX:106-124.

Johansson, Sven-Erik (1969). "Income Taxes and Investment Decisions." Swedish Journal of Economics LXXI:104-110.

Kaplow, Louis, (1986). "An Economic Analysis of Legal Transitions." Harvard Law Review (January).

Kotlikoff, Laurence J. (1992). Generational Accounting: Knowing Who Pays, and When, for What We Spend. New York: The Free Press.

Lyon, Andrew B. (1990). "Invariant Valuation When Tax Rates Change over Time." Journal of Political Economy XCVIII(2, April 1990):433-437.

- (1992). "Tax Neutrality under Parallel Tax Systems." Public Finance Quarterly XX(3, July):338-358.

McLure, Charles E., Jr., Jack Mutti, Victor Thuronyi, and George Zodrow (1990). The Taxation of Income from Business and Capital in Colombia. Duke University Press.

-, and George R. Zodrow (1991). "Implementing Direct Consumption Taxes in Developing Countries." Tax Law Review XLVI(4, Summer):405-487.

Paul, Deborah L. (1997). "The Sources of Tax Complexity." Forthcoming in North Carolina Law Review.

Rose, Manfred, and Rolf Wiswesser (1997). "Tax Reform in Transition Economies: Experiences from Participating in the Croation Tax Reform Process of the 1990s." Forthcoming in Public Finance in a Changing World, Peter Birch Soerensen (ed.). London: Macmillan Press.

Samuelson, Paul A. (1964). "Tax Deductibility of Economic Depreciation to Insure Invariant Valuations." Journal of Political Economy LXXII:604-606.

Sandmo, Agnar (1979). "A Note on the Neutrality of the Cash Flow Corporate Tax." Economic Letters IV:173-176.

Sinn, Hans-Werner (1987). Capital Income Taxation and Resource Allocation. New York: North-Holland.

Shaviro, Daniel (1997). Tax Transitions and Tax Politics. Forthcoming. Chicago: University of Chicago Press.

Shoven, John B., and Jeremy I. Bulow (1975). "Inflation Accounting and Nonfinancial Corporate Profits: Physical Assets." Brookings Papers on Economic Activity 3:557-611.

Wenger, Ekkehard (1983). "Gleichmässigkeit der Besteuerung von Arbeits- und Vermögenseinkünften." Finanzarchiv, 207-252.

Zodrow, George R., (1981). "Implementing Tax Reform." National Tax Journal XXXIV(4, December):401-418.

(1985). "Optimal Tax Reform in the Presence of Adjustment Costs." Journal of Public Economics, XXVII(2, July):211-230.

(1988). "The Windfall Recapture Tax: Issues of Theory and Design." Public Finance Quarterly XVI(4, October):387-424. 